International Business and Global Economy 2019, no. 38, pp. 149-161

Biznes międzynarodowy w gospodarce globalnej 2019, nr 38, s. 149-161

Edited by the Institute of International Business, University of Gdańsk

\title{
Wpływ turystyki na gospodarkę Hiszpanii
}

Celem niniejszego artykułu jest ukazanie wpływu turystyki na gospodarkę hiszpańską. Metodą badawczą jest analiza dostępnych danych statystycznych zgromadzonych przez różne organizacje i instytucje, m.in. OECD, UNWTO oraz Unię Europejską. Artykuł opiera się na pozycjach literaturowych polskich autorów oraz czasopismach i publikacjach hiszpańskojęzycznych. Podstawa teoretyczna pracy ułatwia analizę gromadzonych danych empirycznych. W artykule przedstawiono zależność pomiędzy turystyką a rozwojem gospodarczym Hiszpanii. To zbiór najważniejszych informacji o sytuacji gospodarczej największego kraju Półwyspu Iberyjskiego. Zgromadzone zostały najaktualniejsze dane statystyczne, które pozwalają ocenić sytuację omawianej gospodarki. Warto wspomnieć, iż Hiszpania jako wiodący obszar recepcji turystycznej nieustannie poszukuje innowacji przyciągających turystów. Życie zawodowe wielu Hiszpanów zależy głównie od rozwoju turystyki, dlatego też dążą oni do sprostania oczekiwaniom najbardziej wymagających gości z całego świata.

Słowa kluczowe: turystyka, Hiszpania, turysta

Klasyfikacja JEL: L83, Z32, R0

\section{The impact of tourism on the Spanish economy}

The purpose of this article is to show the influence of tourism on the Spanish economy. The research method is the analysis of available statistical data collected by various organizations and institutions, including OECD, UNWTO and the European Union. The article is based on Polish literature and Spanish magazines and publications. The theoretical basis of the work facilitates the analysis of collected empirical data. The article presents the relationship between tourism and the economic development of Spain. It is a collection of the most important information about the economic situation of the largest country in the Iberian Peninsula. The most up-to-date statistical data have been collected to assess the situation of the said economy. It is worth mentioning that Spain as a leading tourist reception area is constantly looking for innovations that can attract tourists. The professional life of many Spaniards depends mainly on the development of tourism, so they strive to meet the expectations of the most demanding guests from around the world.

Keywords: tourism, Spain, tourist

JEL classification: L83, Z32, R0 


\section{Wprowadzenie}

Turystykę można uznać za zjawisko o charakterze społeczno-kulturowym. Zróżnicowane sposoby spędzania wolnego czasu, regeneracja sil, odpoczynek i różne formy rozrywki to główne atrakcje, jakie muszą oferować przedsiębiorstwa turystyczne, aby zaspokoić potrzeby turystów. Turystyka to biznes, który przynosi ogromne zyski. Co więcej, jest to działalność gospodarcza wymagająca odpowiedniej polityki, wykwalifikowanej kadry, stosownego systemu organizacji oraz zarządzania. $\mathrm{W}$ artykule zestawiono informacje dotyczące wpływu turystyki na gospodarkę Hiszpanii, kraju wyróżniającego się na świecie właśnie pod kątem obsługi ruchu turystycznego.

\section{Turystyka a dochód narodowy}

Ze względu na heterogeniczność turystyki niezwykle trudno jest zmierzyć udział generowanych przez nią zysków $\mathrm{w}$ dochodzie narodowym. Powodem jest tworzenie i realizacja produktów turystycznych partycypujących podmiotów gospodarczych należących do wielu sektorów gospodarki międzynarodowej. Warto dodać, iż w wielu przypadkach produkowane dobra i usługi wykorzystywane są nie tylko przez turystów, udział turystyki w ich konsumpcji jest więc cząstkowy. Należy zatem zadać pytanie, dlaczego ważne jest zmierzenie udziału turystyki $\mathrm{w}$ dochodzie narodowym. Uprawianie turystyki ma z założenia wpływać na poprawę jakości życia i środowiska naturalnego. Turystyka to doznania, wypoczynek, regeneracja sił, wzbogacenie psychiczne człowieka i ochrona zdrowia. Uprawianie turystyki zostałoby $\mathrm{w}$ ogromnym stopniu ograniczone, gdyby wytwórcy usług nie osiągali dochodów dzięki wydatkom ponoszonym przez konsumentów na zakup nowych dóbr i usług współtworzących produkt turystyczny. Wysokość udziału ich dochodów w dochodzie narodowym odzwierciedla rolę i znaczenie turystyki w gospodarce narodowej i wpływa na postrzeganie turystyki przez państwo i prywatnych posiadaczy kapitału jako mniej lub bardziej istotnego sektora gospodarki. To natomiast wpływa na wielkość inwestycji, promocję i wprowadzanie ułatwień prowadzących do rozwoju turystyki. Właśnie dlatego badacze wolą uniknąć "dryfowania po nieuporządkowanych danych" i określić udział turystyki w dochodzie narodowym [Gołembski, 2009].

Usługi uznawane są za główny składnik produktu turystycznego. Nie ma możliwości ich magazynowania, ich sprzedaż jest więc równorzędna z wielkością ich produkcji, a skutkiem nadmiaru zdolności usługowej bardzo często jest jego utrata. Można zatem uznać, iż wydatki na zakup usług turystycznych równają się 
wartości wyprodukowanych usług. Jeśli za podstawę obliczeń przyjmiemy wielkość wydatków na usługi turystyczne, należy konsekwentnie zastosować takie podejście w odniesieniu do pozostałych dóbr konsumpcyjnych i inwestycyjnych. Dobra inwestycyjne nabywane przez przedsiębiorców świadczących usługi turystyczne mogą być także użytkowane przez podmioty gospodarcze, które takich usług nie świadczą, należy zatem spróbować wydzielić takie podmioty w sektorze turystyki. Chcąc zmierzyć udział turystyki w dochodzie narodowym, należy wziąć pod uwagę następujące wydatki:

1. wydatki konsumpcyjne [Gołembski, 2009]:

a. wydatki turystów zagranicznych przyjeżdżających do Hiszpanii w Hiszpanii,

b. wydatki turystów zagranicznych przyjeżdżających do Hiszpanii w ich kraju macierzystym, które wpływają na konta organizatorów turystyki w Hiszpanii,

c. wydatki turystów krajowych w firmach organizujących wyjazdy turystyczne,

d. pozostałe wydatki turystów w Hiszpanii;

2. wydatki inwestycyjne na rozwój produkcji dóbr i usług turystycznych (brane pod uwagę są inwestycje netto w zakup nowych środków trwałych w danym roku, natomiast inwestycje brutto są względnie pomniejszone o wartość amortyzacji):

a. wydatki bezpośrednie przedsiębiorstw,

b. wydatki samorządów terytorialnych:

- bezpośrednie,

- pośrednie;

3. wydatki rządowe na rozwój turystyki:

a. bezpośrednie wsparcie turystyki,

b. wydatki pośrednie.

Wydatki zagranicznych turystów mogą zostać obliczone na podstawie metody pośredniej, która polega na rejestracji wymiany walut. Przykładem może być polski złoty, waluta rzadko wymienialna za granicą, w którą turyści muszą zaopatrzyć się na miejscu. Warto wspomnieć, iż niektórzy turyści ponoszą wydatki na terenie swojego kraju, gdy kupują wycieczki organizowane przez rodzinnych touroperatorów. Jeśli usługodawcy ci współpracują z hiszpańskimi biurami podróży, pewna część wpłaconych przez klientów pieniędzy wpływa także na konto hiszpańskich organizatorów turystyki.

Nieco inaczej oblicza się wydatki turystów krajowych. Część tych wydatków wpływa do kasy biur podróży, część jest zaś wydatkowana u licznych usługodawców w miejscu zamieszkania, w trakcie dojazdów bądź w miejscu recepcji turystycznej [Gołembski, 2009]. Biuro podróży przeznacza pieniądze na zakup imprezy krajowej bądź zagranicznej. W tym drugim wypadku do dochodu narodowego 
należy wliczyć tylko część wydatków pozostającą u organizatora po opłaceniu kosztów refakturowanych za granicą. Takie wydatki można precyzyjnie obliczyć za pomocą metody budżetów rodzinnych.

Kolejna pozycja to wydatki inwestycyjne przedsiębiorstw, które w przypadku firm specjalizujących się w obsłudze ruchu turystycznego (hotele, transport turystyczny, gastronomia, biura podróży, handel artykułami sportowo-turystycznymi, muzea, parki rozrywki) można precyzyjnie obliczyć. Wydatki bezpośrednie wynikają z partycypacji samorządów w budowaniu bazy turystycznej, obiektów sportowo-rekreacyjnych, renowacji dóbr kultury, budowy ścieżek, kładek i innych udogodnień dla turystyki specjalistycznej czy weekendowej [Gołembski, 2009]. Wydatki pośrednie to inwestycje samorządowe w poprawę infrastruktury technicznej, usługowej i ochronę środowiska. Wydatki rządowe na rozwój turystyki mają w znacznym stopniu charakter statutowy. Zalicza się do nich wydatki związane z promocją kraju (wydawnictwa, targi, utrzymywanie ośrodków za granicą), wydatki na kształcenie kadr turystycznych w szkołach i uczelniach państwowych, opracowywanie narodowych planów zagospodarowania turystycznego i programów rozwoju turystyki, utrzymywanie parków narodowych oraz zabytków o znaczeniu ponadregionalnym [Gołembski, 2009].

Warto wspomnieć również o wprowadzonej do nowoczesnej makroekonomii przez Johna Maynarda Keynesa koncepcji mnożnika inwestycyjnego, który dotyczy wpływu inwestycji na wzrost produktu narodowego brutto, jest więc powiązany z wpływem turystyki na gospodarkę każdego kraju. Mnożnik ten pokazuje, że przyrost inwestycji wywołuje nie proporcjonalny, a zwielokrotniony przyrost produkcji i zatrudnienia [Gołembski, 2009]. W skali gospodarki narodowej efekty mnożnikowe podobne do inwestycyjnych wywoływane są przez popyt turystów z zagranicy. Ich pieniądze są wpompowywane w gospodarkę niezależnie od krajowych przepływów finansowych. Stanowią nowy i szybki pieniądz domagający się wydatkowania na produkcję dóbr konsumpcyjnych i dodatkowych usług. Należy dodać, iż zagraniczna turystyka przyjazdowa na masową skalę powoduje konieczność uruchomienia działań dostosowawczych w postaci wzrostu produktu narodowego brutto. Dodatkowym skutkiem zwiększenia się popytu generowanego przez przyrost zagranicznych środków płatniczych jest wzrost inwestycji w sytuacji, gdy możliwości zwiększenia produkcji za pomocą obecnych czynników produkcji, a zwłaszcza kapitału, są ograniczone.

Wielkość mnożnika wywołującego w kraju recepcyjnym rozwój turystyki zależy od [Gołembski, 2009]:

1. ilości pieniądza wpompowywanego do kraju recepcyjnego przez turystów z zagranicy, którego ilość uwarunkowana jest liczbą osób przekraczających granicę, średnimi dziennymi wydatkami i liczbą dni pobytu (warto wspomnieć, iż magnesem przyciągającym obcokrajowców do Hiszpanii mogą być 
walory środowiska naturalnego, szerokie i piaszczyste plaże, idealna pogoda wakacyjna, a także znakomita kuchnia śródziemnomorska);

2. czynników wpływających na kształtowanie się krańcowej skłonności do konsumpcji, a więc od poziomu dochodów i zróżnicowania tego poziomu w różnych grupach społecznych;

3. czynników wpływających na popyt inwestycyjny przedsiębiorstw, który możemy podzielić na:

a. inwestycje nowe,

b. tzw. popyt pośredni (przepływy materialne w pośrednich stadiach produkcji),

c. popyt restytucyjny związany z odtworzeniem środków trwałych.

Do sektora turystyki zaliczamy hotelarstwo, specjalistyczny transport, gastronomię, biura podróży, a także inwestycje w ochronę środowiska, rozwój gospodarki komunalnej, infrastruktury technicznej i usługowej oraz kształtowanie układu komunikacyjnego. Warto podkreślić znaczenie usług noclegowych, gdyż ich kapitałochłonność i długi cykl inwestycyjny sprawia, iż długo dostosowują się do zmian popytu, co jest istotne dla kształtowania się mnożnika. Co więcej, popyt na inwestycje w tym sektorze angażuje znaczny kapitał i wprowadza pieniądze do obiegu gospodarczego. Należy pamiętać o wysokim popycie restytucyjnym na odtworzenie zużytych środków trwałych, do których zaliczane są budynki oraz specjalistyczny sprzęt o krótszym okresie amortyzacyjnym (np. urządzania klimatyzacyjne, wentylacyjne, przeciwpożarowe, gastronomiczne, umeblowanie). Zużycie wspominanego sprzętu jest związane $\mathrm{z}$ intensywnym świadczeniem usług, a te z popytem na usługi i polityką cen.

Ponadto nie można jednoznacznie stwierdzić, iż wpływ turystyki na bilans płatniczy kraju oraz efekty mnożnikowe wywołane przez popyt turystów z zagranicy prowadzą do nieograniczonego rozwoju turystyki. Należy brać pod uwagę potencjalny negatywny wpływ rozwoju turystyki na środowisko, a nie skupiać się tylko na krótkowzrocznej polityce maksymalizacji jednostkowych zysków [Gołembski, 2009].

\section{Ruch turystyczny w Hiszpanii}

Do XIX w. ruch turystyczny nie odgrywał w Hiszpanii znaczącej roli. W latach 30. XIX w. królowa Izabela II wprowadziła modę na plaże wybrzeża kantabryjskiego (letnie rezydencje w San Sebastian i Santander), lecz nie wpłynęło to na ożywienie turystyki. W połowie XIX w. nastąpił renesans uzdrowisk hiszpańskich z czasów rzymskich i arabskich - dużym uznaniem cieszyły się szczególnie uzdrowiska górskie: Alceda, Marmolejo, Ontaneda czy Santa Agueda. W tym samym czasie zaczęto również częściej odwiedzać Wyspy Kanaryjskie i Baleary. 
Wraz ze stabilizacją sytuacji politycznej i gospodarczej w Europie na przełomie wieków nastąpił wzrost liczby przyjazdów turystycznych do Hiszpanii, co pociągnęło za sobą zmianę i rozbudowę bazy noclegowej. Miejsce małych i skromnych zajazdów, tzw. fondas, które obok bogatych rezydencji stanowiły do tamtej pory bazę noclegową kraju, zajęły hotele. Pierwsze z nich wybudowano jeszcze pod koniec XIX w. na Wyspach Kanaryjskich, Balearach, w Madrycie, San Sebastian, Santander i Barcelonie.

Wsparcie kredytowe rządu hiszpańskiego umożliwiło rozwój przemysłu hotelowego, co doprowadziło do zainwestowania znacznych funduszy w infrastrukturę turystyczną, w szczególności w latach 1961-1970, kiedy to nastąpił wzrost liczby miejsc noclegowych o 335\% [Koliba, 1997].

Hiszpania zaliczana jest do krajów wysoko rozwiniętych. PKB per capita w 2010 r. wyniósł 31 tys. USD [Kurek, 2012]. W latach 2012-2014 wartość tego wskaźnika znacząco spadła, by w 2017 r. ponownie wzrosnąć do poziomu 32 tys. USD [Trading Economics, 2019].

Rozwój gospodarczy Hiszpanii rozpoczął się w latach 60. XX w., natomiast napływ kapitału z zagranicy nabrał tempa w latach 70. Należy wspomnieć, iż kraj ten charakteryzują duże dysproporcje w rozwoju gospodarczym między poszczególnymi regionami. Najwyższy poziom rozwoju zauważalny jest w regionie Madrytu, Katalonii i Baskonii, najsłabiej rozwinięte są natomiast regiony położone wewnątrz kraju, tj. Estremadura i Kastylia-La Mancha, oraz częściowo Andaluzja i Galicja. Należy dodać, iż różnica w zamożności najbogatszych i najbiedniejszych regionów jest prawie dwukrotna. W związku z kryzysem światowym w latach 2008-2009 Hiszpania odnotowała duży spadek w produkcji przemysłowej (aż o 16\%) oraz wzrost bezrobocia (z 8\% w 2007 r. do 19\% w 2009 r.) [Kurek, 2012; Bernaś, 2015].

Należy podkreślić, że bardzo duże znaczenie dla rozwoju turystyki przyjazdowej mają połączenia lotnicze z Hiszpanią. Kraj ten dysponuje trzydziestoma międzynarodowymi portami lotniczymi, z których największe to Bajas w Madrycie, El Prat w Barcelonie i San Juan w Palma de Mallorca. Co więcej, istnieje tam dobrze rozwinięta sieć połączeń drogowych i kolejowych, powiększa się też sieć autostrad i dróg ekspresowych (14,3 tys. km w 2008 r.) [Kurek, 2012]. Głównym węzłem drogowym jest stolica, Madryt, łącząca pozostałe regiony kraju sześcioma liniami autostradowymi. Istotne znaczenie turystyczne mają również drogi szybkiego ruchu i autostrady wzdłuż wybrzeży Atlantyku i Morza Śródziemnego. Linia kolejowa w Hiszpanii jest również nieustannie rozwijana i modernizowana. Hiszpanie nastawiają się głównie na realizację szybkich połączeń.

Analizując Hiszpanię jako region turystyczny, należy zwrócić również uwagę na strefę klimatyczną, w której się ona znajduje. Terytorium Hiszpanii charakteryzuje się zróżnicowanymi warunkami klimatycznymi, na które wpływa ukształtowanie powierzchni oraz oddziaływanie mas powietrza znad Morza Śródziemne- 
go i Oceanu Adriatyckiego. Północna i północno-zachodnia część kraju wyróżnia się klimatem umiarkowanym o stosunkowo dużej wilgotności. W centrum półwyspu klimat jest bardziej suchy z niewielką ilością opadów w ciągu roku i gorącym latem. Południowa i południowo-wschodnia część kraju odznacza się ciepłym, suchym klimatem, a duże nasłonecznienie w ciągu roku sprawia, że średnia temperatura w najcieplejszym miesiącu wynosi tam 29 stopni Celsjusza. W tej części kraju znajdują się najchętniej wybierane obszary recepcji turystycznej: Andaluzja, Wyspy Kanaryjskie i Baleary.

Warto również wspomnieć o bardzo dobrze rozwiniętej bazie noclegowej. Według danych z 2009 r. Hiszpania dysponowała łącznie ok. 3 mln miejsc noclegowych, w tym 1,61 mln w bazie hotelowej, 760 tys. w sezonowych obiektach kempingowych oraz 520 tys. w apartamentach turystycznych (zwłaszcza na Wyspach Kanaryjskich, gdzie stanowią one ok. 40\% ogółu miejsc noclegowych) [Kurek, 2012]. Najwięcej obiektów noclegowych znajduje się w obszarach nadmorskich położonych wzdłuż wybrzeża Morza Śródziemnego.

Turystyka to jeden z najważniejszych sektorów gospodarki Hiszpanii - ma ok. 11\% udziału w PKB i generuje prawie co dziewiąte miejsce pracy. Dane dotyczące krajów OECD zebrane przez Światową Organizację Turystyki (United Nations World Tourism Organization - UNWTO) plasują Hiszpanię na pierwszej pozycji, co oznacza, że w żadnym innym kraju udział turystyki w PKB nie jest wyższy niż Hiszpanii. Można zatem powiedzieć, iż podstawowym sektorem hiszpańskiej gospodarki jest właśnie turystyka.

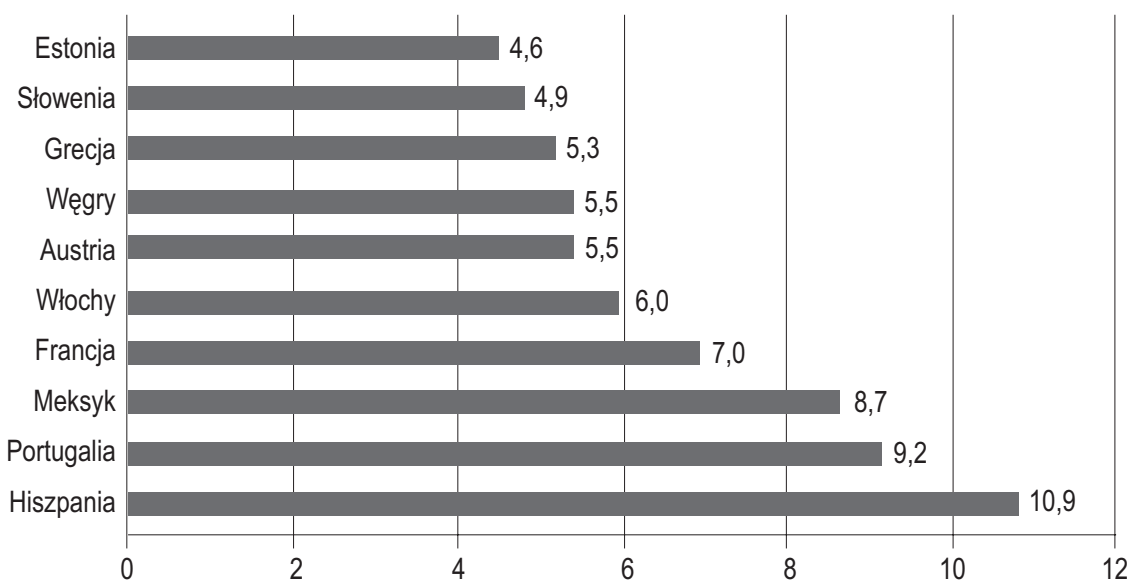

Rys. 1. Bezpośredni udział turystyki w krajach OECD w 2018 r., \% PKB Źródło: Opracowanie własne na podstawie: [UNWTO, 2018].

Znając już pozycję Hiszpanii w rankingu krajów OECD, warto również przeanalizować dane dotyczące rynku turystycznego w samej Hiszpanii. Tabela 1 
przedstawia liczbę przedsiębiorstw i wielkość zatrudnienia w turystyce w Hiszpanii na przestrzeni lat 2013-2016. Należy zauważyć, iż trend zwyżkowy widoczny jest $\mathrm{w}$ różnych segmentach turystyki.

Tabela 1. Liczba przedsiębiorstw i wielkość zatrudnienia $\mathrm{w}$ turystyce $\mathrm{w}$ Hiszpanii $\mathrm{w}$ latach 2013-2016

\begin{tabular}{|c|c|c|c|c|c|}
\hline \multirow{2}{*}{ Wyszczególnienie } & $\begin{array}{c}\text { Liczba } \\
\text { przedsię- }\end{array}$ & \multicolumn{4}{|c|}{ Zatrudnienie } \\
\hline & 2016 & 2013 & 2014 & 2015 & 2016 \\
\hline Przemysł turystyczny & 669150 & 2083544 & 2203044 & 2322381 & 2447758 \\
\hline Usługi noclegowe & 204213 & 313190 & 321742 & 344323 & 395968 \\
\hline Usługi hotelowe i podobne & 15053 & 276159 & 281373 & 303249 & 354717 \\
\hline Usługi gastronomiczne & 264320 & 1019399 & 1082036 & 1160832 & 1208180 \\
\hline Transport pasażerski & 63208 & 257342 & 267550 & 264877 & 269001 \\
\hline Transport lotniczy & 245 & 39516 & 41501 & 39757 & 36373 \\
\hline Transport kolejowy & 68 & 26692 & 24614 & 22562 & 25981 \\
\hline Transport drogowy & 62477 & 185334 & 191924 & 193646 & 197406 \\
\hline Transport morski & 418 & 5799 & 9512 & 8912 & 9241 \\
\hline $\begin{array}{l}\text { Usługi dodatkowe transportu } \\
\text { turystycznego }\end{array}$ & 23817 & - & - & - & - \\
\hline $\begin{array}{l}\text { Wypożyczanie środków } \\
\text { transportu }\end{array}$ & 7306 & 170216 & 178068 & 182726 & 204261 \\
\hline Usługi agencji turystycznych & 16579 & 55724 & 62144 & 74724 & 65108 \\
\hline $\begin{array}{l}\text { Usługi twórczości artystycznej } \\
\text { i spektakle }\end{array}$ & 36441 & 89369 & 96630 & 99411 & 97179 \\
\hline $\begin{array}{l}\text { Usługi sportowe, rekreacyjne } \\
\text { i rozrywkowe }\end{array}$ & 53266 & 178305 & 194874 & 195490 & 208060 \\
\hline
\end{tabular}

Źródło: Opracowanie własne na podstawie: [OECD, 2018; Bernaś, 2015, s. 128].

Warto również przeanalizować dane dotyczące przedsiębiorstw działających na rynku turystycznym w Hiszpanii, skupiając się głównie na turystyce krajowej, przyjazdowej i wyjazdowej. Należy też podkreślić, iż w 1995 r. do Hiszpanii przyjechało 63,3 mln osób, a już w 2017 r. liczba ta wzrosła do 81,8 mln. Wpływy z turystyki wyniosły wówczas 25,3 mld USD [Maik, 1999, s. 82].

Dane przedstawione w powyższej tabeli ukazują tendencję zwyżkową w turystyce przyjazdowej - coraz więcej turystów przyjeżdża do Hiszpanii i zostaje tam na co najmniej jedną noc. Hiszpania bardzo intensywnie się rozwija, wprowadza też dużo innowacji, a rządowi hiszpańskiemu zależy na przyciągnięciu nowych inwestorów. Wśród turystów najczęściej odwiedzających Hiszpanię znajdują się Brytyjczycy, Francuzi i Niemcy. 
Tabela 2. Turystyka krajowa, przyjazdowa i wyjazdowa w Hiszpanii w latach 2013-2016

\begin{tabular}{|c|c|c|c|c|}
\hline Wyszczególnienie & 2013 & 2014 & 2015 & 2016 \\
\hline \multicolumn{5}{|c|}{ Przepływ turystyczny, w tys. } \\
\hline \multicolumn{5}{|l|}{ Turystyka krajowa } \\
\hline łączne podróże krajowe & 398423 & 462761 & 345599 & 370397 \\
\hline goście nocujący (turyści) & 144527 & 139615 & 123923 & 132201 \\
\hline jednodniowi goście (wycieczki) & 253896 & 323146 & 221676 & 238196 \\
\hline noce we wszystkich rodzajach zakwaterowania & 657780 & 621835 & 476459 & 508758 \\
\hline hotele i podobne obiekty & 97100 & 95568 & 84074 & 91254 \\
\hline inne instytucje kolektywne & 42911 & 41577 & 27574 & 32702 \\
\hline kwatery prywatne & 517770 & 484690 & 364810 & 384802 \\
\hline \multicolumn{5}{|l|}{ Turystyka przyjazdowa } \\
\hline całkowita liczba przyjazdów międzynarodowych & 103231 & 107614 & 109834 & 115561 \\
\hline goście nocujący (turyści) & 60675 & 64995 & 68175 & 75315 \\
\hline jednodniowi goście (wycieczki) & 42555 & 42619 & 41659 & 40246 \\
\hline \multicolumn{5}{|l|}{ najważniejsze rynki: } \\
\hline Wielka Brytania & 14334 & 15007 & 15764 & 17675 \\
\hline Francja & 9539 & 10616 & 11504 & 11259 \\
\hline Niemcy & 9857 & 10422 & 10260 & 11209 \\
\hline kraje nordyckie & 4875 & 5045 & 5009 & 5129 \\
\hline Włochy & 3225 & 3698 & 3907 & 3969 \\
\hline noce we wszystkich rodzajach zakwaterowania & 542631 & 575795 & 597319 & 593417 \\
\hline hotele i podobne obiekty & 267359 & 279623 & 288472 & 280646 \\
\hline inne instytucje kolektywne & 31141 & 34830 & 41004 & 26547 \\
\hline kwatery prywatne & 244132 & 261342 & 266654 & 286224 \\
\hline \multicolumn{5}{|l|}{ Turystyka wyjazdowa } \\
\hline całkowite międzynarodowe wyjazdy & 13434 & 13952 & 15706 & 16144 \\
\hline goście nocujący (turyści) & 11246 & 11783 & 12488 & 13272 \\
\hline jednodniowi goście (wycieczki) & 2188 & 2169 & 3218 & 2872 \\
\hline \multicolumn{5}{|l|}{ najpopularniejsze miejsca docelowe: } \\
\hline Francja & 1868 & 2124 & 1836 & 2147 \\
\hline Portugalia & 1335 & 1503 & 1670 & 1650 \\
\hline Włochy & 1107 & 1207 & 1263 & 1451 \\
\hline Wielka Brytania & 995 & 993 & 1188 & 1299 \\
\hline Niemcy & 638 & 688 & 891 & 804 \\
\hline \multicolumn{5}{|c|}{ Potrzeby turystyczne i wydatki, w mln EUR } \\
\hline \multicolumn{5}{|l|}{ Turystyka przyjazdowa } \\
\hline całkowite międzynarodowe wpływy & 47164 & 49010 & 50893 & 54516 \\
\hline międzynarodowe potwierdzenia podróży & 47164 & 49010 & 50893 & 54516 \\
\hline \multicolumn{5}{|l|}{ Turystyka wyjazdowa } \\
\hline całkowite wydatki międzynarodowe & 12360 & 13572 & 15654 & 18247 \\
\hline międzynarodowe wydatki na podróże & 12360 & 13572 & 15654 & 18247 \\
\hline
\end{tabular}

Źródło: Opracowanie własne na podstawie: [OECD, 2018]. 
Hotele nadal są głównym elementem bazy noclegowej, lecz pojawia się coraz więcej kwater prywatnych. Coraz bardziej popularne stają się platformy internetowe, na których turyści mogą wyszukać pokój lub mieszkanie na wynajem na kilka dni. Przykładem takiego udogodnienia jest platforma Airbnb, gdzie każdy zarejestrowany użytkownik może dodać opinię na temat noclegu, z którego miał okazję skorzystać. Hiszpanie również lubią podróżować. Najczęściej wybierają Francję, Portugalię, Włochy i Wielką Brytanię. Zauważa się wzrost liczby osób nocujących za granicą, co pozytywnie wpływa na sektor turystyki zagranicznej.

Jak wspomniano, turystyka jest jednym z filarów hiszpańskiej gospodarki i motorem napędowym rozwoju społecznego. Odpowiada za 11,1\% PKB i 13\% zatrudnienia i nadal znacząco przyczynia się do zrekompensowania deficytu handlowego w tym kraju, przynosząc wpływy w wysokości 54,5 mld EUR (wzrost o 7,1\% w porównaniu z 2015 r.). Przy 75,3 mln przyjazdów turystycznych (wzrost o 10,5\% ) i 54,7 mld EUR wpływów z podróży międzynarodowych (wzrost o 7,2\%) w 2016 r. Hiszpania zajęła pod tymi względami odpowiednio trzecie i drugie miejsce na świecie [OECD, 2018]. Dane dotyczące międzynarodowej turystyki przyjazdowej w 2017 r. również wskazują, iż Hiszpania znajduje się na podium.

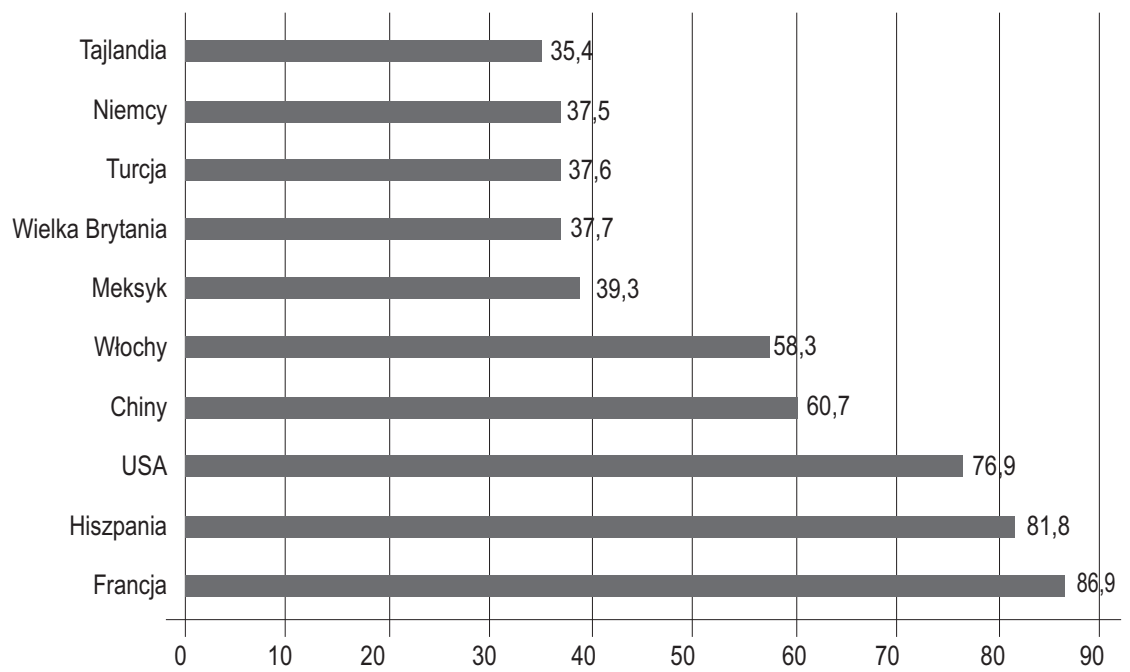

Rys. 2. Międzynarodowa turystyka przyjazdowa w 2017 r., w mln Źródło: Opracowanie własne na podstawie: [UNWTO, 2019].

Według hiszpańskiego Narodowego Instytutu Statystycznego w Hiszpanii wzrasta także zainteresowanie turystyką krajową. W 2016 r. nastąpił 3,7\% wzrost liczby podróży w stosunku do roku wcześniejszego. Okazuje się, że Hiszpanie podróżują głównie w obrębie Hiszpanii. Największymi hiszpańskimi podróżnikami są mieszkańcy Madrytu, Nawarry oraz Aragonii, którzy zazwyczaj podró- 
żują w celach biznesowych [El País, 2017]. Według badania przeprowadzonego w 2017 r. przez „El País”, większość (91,4\%) wyjazdów turystycznych Hiszpanów odbywa się w granicach ich kraju. Najczęściej odwiedzanym w 2016 r. regionem była Andaluzja (17,5\%), następnie Katalonia (12,3\%), Walencja (9,4\%) i Kastylia i León $(9,4 \%)$. Najrzadziej Hiszpanie podróżują do regionów La Rioja $(0,8 \%)$ i Nawarra $(1,4 \%)$ oraz na Baleary $(1,8 \%)$ [El País, 2017].

Badania przeprowadzone w drugim kwartale 2019 r. ukazują, iż hiszpańskie społeczeństwo jako obszary recepcji turystycznej najczęściej wybierało m.in Andaluzję (16\%), Katalonia (14,4\%) i Comunidad Valenciana (10,5\%), natomiast regiony takie jak La Rioja $(0,9 \%)$, Nawarra $(1,4 \%)$ czy Baleary $(1,6 \%)$ odwiedzane były przez hiszpańskich turystów najrzadziej.

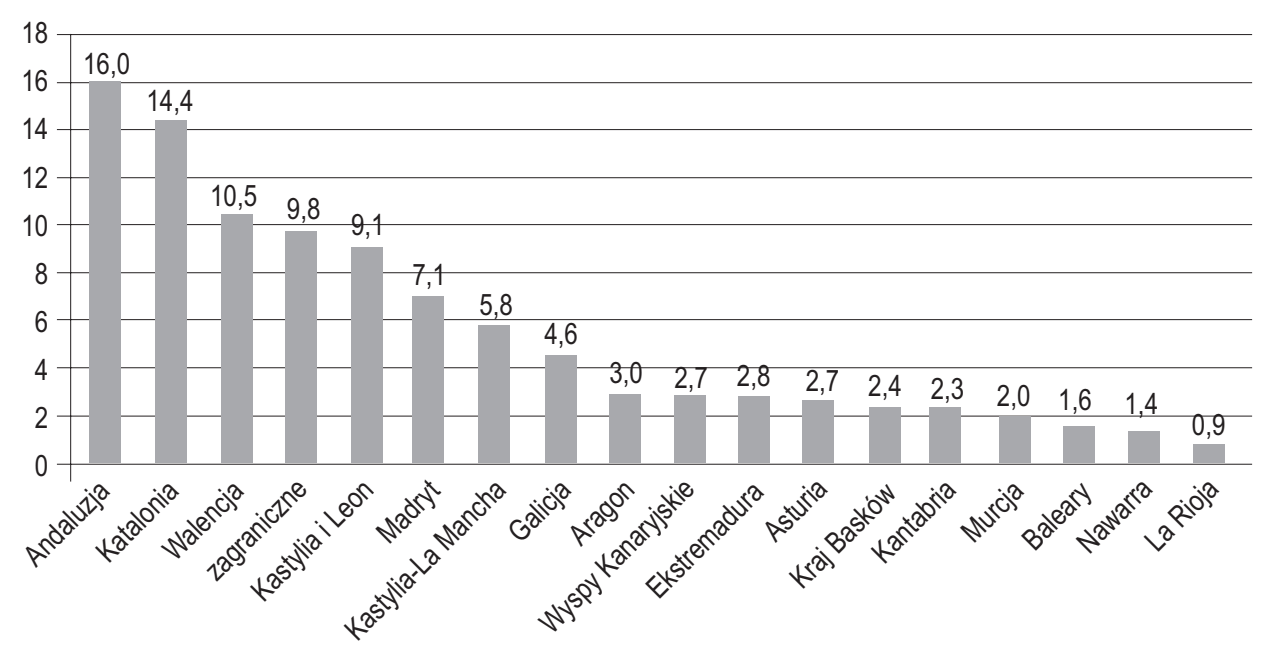

Rys. 3. Podróże hiszpańskich turystów według miejsca docelowego, w \% Źródło: Opracowanie własne na podstawie: [El Economista, 2019].

Stosunkowo najwięcej podróżnych stanowili mieszkańcy Madrytu (1393 podróży na 1000 mieszkańców), Kraju Basków (1256 podróży na 1000 mieszkańców) i Aragonii (1240 podróży na 1000 mieszkańców). Najmniej podróżujących stanowili mieszkańcy Wysp Kanaryjskich (757 podróży na 1000 mieszkańców), Balearów (761 podróży na 1000 mieszkańców) i Murcji (768 podróży na 1000 mieszkańców) [El Economista, 2019].

Hiszpańscy konsumenci-turyści decydują się na podróże po kraju ze względu na niższe koszty (dzienny koszt na osobę wynosi średnio 44 euro, częściowo dlatego, że transport jest tańszy). Ponadto krajobraz Hiszpanii jest bardzo zróżnicowany, każdy może więc znaleźć region, w którym chętnie spędzi wakacje. 


\section{Hiszpania jako lider turystyki}

Warto wspomnieć, iż co roku wzrasta w Hiszpanii liczba chińskich i rosyjskich turystów, do czego prawdopodobnie przyczynił się rozwój sieci lotniczej i stosunków międzynarodowych na szczeblu rządowym. W 2017 r. po raz drugi z rzędu Światowe Forum Gospodarcze ogłosiło Hiszpanię najlepszym krajem pod względem konkurencyjności turystyki. Należy dodać, iż krajowa odpowiedzialność za turystykę spoczywa na nowo mianowanym Ministerstwie Energii, Agencji Turystyki i Cyfryzacji, nazywanym także Sekretariatem Stanu ds. Turystyki. Zmieniona nazwa Agencji odzwierciedla rosnące zainteresowanie innowacjami i technologią cyfrową $\mathrm{w}$ tym sektorze. Rola państwa polega na zapewnianiu dobrych stosunków międzynarodowych, promocji i marketingu turystyki za granica, prowadzeniu polityki turystycznej oraz ogólnej regulacji działalności turystycznej i narodowej gospodarki planowania, która jest kluczowym elementem. Sekretariat odpowiada za rozwijanie, koordynowanie i wdrażanie polityki turystycznej, a także stosunki instytucjonalne na poziomie krajowym i międzynarodowym. Sekretariat koordynuje trzy podmioty na poziomie krajowym: Turespaña, Paradores de Turismo S.A. i SEGITTUR (Państwowe Towarzystwo Zarządzania Innowacjami i Technologiami Turystycznymi).

Hiszpański Sekretariat ds. Turystyki pracuje nad nową strategią krajową. Priorytety obejmują dywersyfikację produktów, zrównoważony rozwój i koncentrację na kluczowych segmentach rynku (np. na "kosmopolitach” o większej sile nabywczej i zainteresowaniu kulturą, sztuką, gastronomią, turystyką doświadczeń i zakupami).

Hiszpański model rozwoju turystyki opiera się na zrównoważonym rozwoju, innowacjach i wiedzy, digitalizacji, specjalizacji i jakości. Zrównoważony rozwój wymaga świadczenia wysokiej jakości usług noclegowych i zachęca do dłuższych pobytów, jak również wiąże się z innowacyjnością w zakresie wykorzystywania danych, digitalizacji i „inteligentnych" miejsc turystycznych. Digitalizacja wszystkich podsektorów łańcucha turystycznego jest kluczem do modernizacji sektora. W tym kontekście hiszpański Sekretariat ds. Turystyki wspólnie z UNWTO w lutym $2017 \mathrm{r}$. zorganizował pierwszy międzynarodowy kongres na temat inteligentnych miejsc docelowych w Murcji w Hiszpanii. SEGITTUR jest liderem promowanego przez Sekretariat projektu „Smart Destinations”, który ma na celu poprawę pozycji Hiszpanii jako światowego obszaru recepcji turystycznej. Metodologia wspiera innowacje, zrównoważony rozwój i konkurencyjność na poziomie lokalnym poprzez rozwój i wdrażanie ICT w celu stworzenia zróżnicowanych i wysoce konkurencyjnych usług [Thinktur, 2019]. 


\section{Podsumowanie}

Walory przyrodnicze, zabytki architektoniczne oraz nowoczesne kompleksy hotelowo-wypoczynkowe przyciągają do Hiszpanii turystów z całego świata. Turystyka międzynarodowa spowodowała rozwój zagospodarowania wielu wybrzeży (Costa Brava, Costa Dorada, Costa del Sol, Costa del Azahar). Warto wspomnieć, iż istotnymi obszarami recepcji turystycznej są również wyspy (Kanaryjskie i Baleary), góry Sierra Nevada i Sierra Guadarrana z ośrodkami sportów zimowych oraz zabytkowe miasta, takie jak Madryt, Toledo czy Granada.

Hiszpania nie spoczywa na laurach i dąży do promocji swojego kraju na każdy możliwy sposób. Rząd hiszpański podejmuje różne działania mające na celu wsparcie sektora turystyki, zwłaszcza dotyczące nowych technologii, i decyduje się na wprowadzanie nowinek technologicznych, aby zwiększyć konkurencyjność i atrakcyjność tego jedynego w swoim rodzaju kraju.

Bibliografia

Bernaś B., 2015, Finanse turystyki zagranicznej, CeDeWu, Warszawa.

El País, 2017, Así viaja el turista español: visita otros lugares de España y gasta sobre todo en bares, https://elpais.com/economia/2017/03/28/actualidad/1490692928_042671.html [dostęp: 13.11.2019].

El Economista, 2019, ¿Dónde viajan los españoles? Andalucía, Cataluña y la Comunidad Valenciana, los destinos preferidos, https://www.eleconomista.es/economia/noticias/10120761/ 10/19/Los-espanoles-viajaron-menos-entre-abril-y-junio-pero-gastaron-un-3-mas-con11430-millones.html [dostęp: 24.11.2019].

Gołembski G., 2009, Kompendium wiedzy o turystyce, Wydawnictwo Naukowe PWN, Warszawa.

Koliba A., 1997, Hiszpania, [w:] J. Warszyńska, Geografia turystyczna świata cz. 1, Wydawnictwo Naukowe PWN, Warszawa.

Kurek W., 2012, Regiony turystyczne świata. cz. 1., Wydawnictwo Naukowe PWN, Warszawa.

Maik W., 1999, ABC ŚWIAT, Europa II, Wydawnictwo Kurpisz SA, Poznań.

OECD, 2018, Tourism Trends and Policies 2018, https://www.oecd-ilibrary.org/docserver/ tour-2018-en.pdf?expires $=1574255595 \&$ id $=\mathrm{id} \&$ accname $=$ guest $\&$ checksum $=$ C61D5 E3AC4B0E56253A27DD3C431F822 [dostęp: 20.11.2019].

Thinktur, 2019, http://www.thinktur.org/media/TENDENCIAS.pdf [dostęp: 10.11.2019].

Trading Economics, 2019, https://pl.tradingeconomics.com/spain/gdp-per-capita [dostęp: 13.11.2019].

UNWTO, 2017, https://www.e-unwto.org/doi/pdf/10.18111/9789284419029 [dostęp: 13.11.2019].

UNWTO, 2018, European Union Tourism Trends, https://www.e-unwto.org/doi/book/ 10.18111/ 9789284419470 [dostęp: 24.11.2019].

K. Wysocka (@) katarzyna.wysocka@ue.poznan.pl

Katedra Zarządzania Międzynarodowego, Uniwersytet Ekonomiczny w Poznaniu, al. Niepodległości 10, 61-875 Poznań, Polska 